\title{
To study the incidence of contact hypersensitivity to commonly used topical antibacterials
}

\author{
S Malhotra, S Dewan, A Singal, M Kaur
}

\begin{abstract}
Citation
S Malhotra, S Dewan, A Singal, M Kaur. To study the incidence of contact hypersensitivity to commonly used topical antibacterials. The Internet Journal of Dermatology. 2009 Volume 8 Number 1.
\end{abstract}

DOI: $\underline{10.5580 / 2743}$

\begin{abstract}
Use of topical antibacterial therapy forms anchor sheet of treatment in dermatology but chances of developing problems with the use of this therapy cannot be ignored. 300 individuals attending Dermatology OPD were patch tested for 13 topical antibacterials brands by using 3900 indigenously designed Finn chamber discs. Sensitivities were recorded after 48 \& 96 hours. $83 / 3900(2.13 \%)$ patches in 53/300(17.67\%) individuals tested positive. Incidence of reactivity was seen in the descending order as: Neosporin (16.67\%)à Soframycin (3.33\%)àFuracin (3.33\%)àEnsamycin (3.33\%)àSilversulfadiazine (2\%)àEryacne (2\%)àMetronidazole (2\%)àDettol (1.33\%)àBetadine(1.0\%)àClindacA gel(0.67\%)àMupirax ointment( $0.33 \%)$ àFucidin ointment( $0 \%$ ). Majority of cases i.e. $32 / 53(60.38 \%)$ tested positive to only one antibacterial, $15 / 53(28.30 \%)$ cases showed sensitivity to two antibacterials, $4 / 53(7.55 \%)$ cases showed sensitivity to three antibacterials and $1 / 53(1.89 \%)$ case each showed sensitivity to four \& five topical antibacterials respectively. Cross sensitivity was also observed among Neosporin, Soframycin \& Ensamycin. Indigenously designed Finn chamber used in this study proved to be handy, time saving, economical \& ideal. Neosporin(Neomycin) was the commonest sensitiser while Fucidin (Fusidic acid) \& Mupirax (Mupirocin)were least sensitizing. The last two antibacterials can be safely recommended for topical usage.
\end{abstract}

\section{INTRODUCTION}

Topical antibacterials find a wider use in different specialties like medicine, dermatology, ophthalmology and surgery. They can be both antibiotics \& antiseptics. Topically used medicaments contribute $14-40 \%$ cases of allergic contact dermatitis. ${ }^{1}$ The incidence of contact allergy to a medicament may also be an indicator of degree of usage of that particular topical antibacterial in a given community. In India, Nitrofurazone \& Neomycin are the most common sensitizers. ${ }^{2}$ Contact dermatitis should be considered if there is insidious aggravation of pre existing dermatosis or the skin lesions stop showing any improvement.

Contact dermatitis to the offending drug can be established by two methods-avoiding the suspected medicament for some period and then re-exposing to the same drug or by patch testing technique. The later provides an accurate, scientific, time preventing results which are very well applicable in vivo. ${ }^{3}$ This technique also helps us to discover latent hypersensitivity in a given population and the knowledge gained can be made use in appropriate selection of the topical antibacterials in better patient management. ${ }^{2}$

\section{AIMS \& OBJECTIVES}

The present study envisaged to find out the incidence of contact and cross sensitization to topically used common antibacterials.

\section{MATERIAL \& METHODS}

300 cases attending Dermatology OPD in a tertiary care hospital of Government Medical College, Amritsar (India) were randomly selected \& patch tested with 13 commercially available commonly used antibacterials.

It was ensured that none of these patients selected were suffering from any allergic disorder/generalized eczema / urticaria or taking antihistaminics and/or steroids. In case of patients forthcoming with history of usage of antibacterials, reason of usage $\&$ any local or systemic reaction with its use was also recorded.

\section{PATCH TEST UNIT}

Patch test units including original unit of Jadassohn, Al-test, 
and Finn-chamber have been used. These units are expensive $\&$ have drawbacks.

An ideal patch test unit is the one which should be handy and where smallest amount of possible test material can be used with minimum skin irritation. The test reaction should be localized to limited area of skin and above all should be economical. All these characteristics were kept in mind in designing an indigenously modified Finn chamber. This modified version of Finn Chamber was made out of indigenously available wastes consisting of aluminium discs $7 \mathrm{~mm}$ in diameter with $1 \mathrm{~mm}$ elevated edges. These aluminium discs were obtained from the tops of empty injection vials used in hospital OPDs \& wards. The sharp edges were smoothened before sticking on the micropore tape.

In each patient, 2 strips of micropore tapes ( 8 discs on one strip \& 6 discs on second strip) were applied on the back of patient-one on left $\&$ other on right side of the vertebral column i.e. test material composed of topical antibacterials was applied as 13 discs and one disc was kept empty.

Test material was applied directly into the hollow of aluminium discs more than half of their volume. One disc was kept empty to rule out reaction to disc material (aluminium) \& same as control. The patients were asked to report after 48 hours when both the strips were removed. Results were read after one hour so as to wane off the pressure effect of patches \& discs. Second reading was taken after 96 hours. The results were recorded and inferred as follows:

\section{Figure 1}

$\begin{array}{ll}\text { Result } & \text { Clinical picture } \\ +/- & \text { Faint Erythema } \\ + & \text { Erythema, infiltration \& papules } \\ ++ & \text { Erythema, infilteration, papules, Vesicles } \\ +++ & \text { Bullous reaction } \\ & \\ --\ldots & \text { No change at test site } \\ \text { IR } & \text { Irritant reaction } \\ \text { NT } & \text { Not tested }\end{array}$

Interpretation

Doubtful reaction

Weakly positive

Strongly positive

Extremely positive

Negative result

$\cdots$

\section{RESULTS}

The demographic characteristics of patients enrolled in the study are shown in Table I.

\section{Figure 2}

Table I: Demographic characteristics of the study cases $(n=30)$

\section{Characteristics}

n (percentage)

No of patients patch tested

Age group (in years)

11-20

$115(38.33 \%)$

21-30

102(34\%)

$31-40$

$51(17 \%)$

41-50

$20(6.66 \%)$

51\& above

$12(4 \%)$

Age range

14-60 years

Gender

Males

$169(56.33 \%)$

Females

$131(43.67 \%)$

Total

300

Occupation

Housewives

$80(26.67 \%)$

Students

$80(26.67 \%)$

Businessmen

$26(8.67 \%)$

Labourers

$24(8.00 \%)$

Farmers

$15(5.00 \%)$

Professional

$18(6.00 \%)$

Teachers

$5(1.66 \%)$

Drivers

Others

$48(16.00 \%)$

\section{POSITIVE PATCH TESTING}

3900 aluminium discs were used to patch test 13 topical antibacterials (Table II) in 300 cases. Clear cut positive reaction was seen in 69/3900(1.76\%) sites, while 14 patches showed doubtful results. Final reading taken after 96 hours showed positively in 83/3900(2.13\%) sites in 53(17.67\%) cases. Out of 53 cases tested positive, 23(43\%) were males $\& 30(56.6 \%)$ cases were females respectively. The age of these positive patients ranged between 13-60 years. Majority of them were housewives $(37.745 \%)$. 


\section{Figure 3}

Table II: Showing Positive Patch Test Incidence to various topical antibacterials.

\begin{tabular}{|c|c|c|c|c|c|c|}
\hline \multirow[t]{2}{*}{$\begin{array}{l}\text { Topical antibacterial } \\
\text { tested(Brand name) }\end{array}$} & \multirow[t]{2}{*}{ Constituents of brand } & \multirow{2}{*}{\begin{tabular}{l|}
$\begin{array}{l}\text { No. of } \\
\text { patches }\end{array}$ \\
applied \\
$(\mathrm{n}=3900)$
\end{tabular}} & \multicolumn{2}{|c|}{$\begin{array}{l}\text { Positive } \\
\text { patches after } \\
48 \text { hrs. }\end{array}$} & \multicolumn{2}{|c|}{$\begin{array}{l}\text { Positive } \\
\text { patehes after } \\
96 \mathrm{hrs} \text {. }\end{array}$} \\
\hline & & & na. & \%age & na. & \%age \\
\hline Neosporin & $\begin{array}{l}\text { Polymyxin B, Sulphate } \\
\text { Zinc bacitracin, } \\
\text { Neomycin sulphate }\end{array}$ & 300 & 13 & 4.3 & 20 & 6.67 \\
\hline Erytop & Erythromycin (3\%) & 300 & 5 & 1.66 & 5 & 1.67 \\
\hline Erycane & Erythromycin (4\%) & 300 & 6 & 2.00 & 6 & 2.00 \\
\hline Soframycin skin cream & Framycetin(1\%) & 300 & 7 & 2.33 & 7 & 3.33 \\
\hline Furacin cream & Nitrofurazone $(0.2 \%)$ & 300 & 9 & 3.00 & 10 & 3.33 \\
\hline Ensamycin cream) & $\begin{array}{l}\text { Sisomyein sulphate- } \\
(0.1 \%)\end{array}$ & 300 & 8 & 2.67 & 10 & 3.33 \\
\hline Fucidin ointment & Sodium Fusidate (2\%) & 300 & 0 & 0 & 0 & 0 \\
\hline Clindac A gel & $\begin{array}{l}\text { Clindamyein phosphate- } \\
(1 \%)\end{array}$ & 300 & 2 & 0.67 & 2 & 0.67 \\
\hline $\begin{array}{l}\text { Silver sulphadiazine } \\
\text { eream }\end{array}$ & Silver sulphadiazine-(1\%) & 300 & 5 & 1.66 & 6 & 2.00 \\
\hline Metrogyl gel & Metronidazole (1\%) & 300 & 6 & 2.00 & 6 & 2.00 \\
\hline Mupirax ointment & Mupirocin (2\%) & 300 & 1 & 0.33 & 1 & 0.33 \\
\hline Betadine ointment & Povidone iodine (5\%) & 300 & 3 & 1.00 & 3 & 1.00 \\
\hline Dettol eream & Chloroxylenol $(0.8 \%)$ & 300 & 4 & 1.33 & 4 & 1.33 \\
\hline Total & & 3900 & 69 & 1.76 & 83 & 2.13 \\
\hline
\end{tabular}

\section{(B) DEGREE OF SENSITIVITY IN POSITIVE PATCHES}

After 48 hrs, only 3/69(4.35\%) patches showed (++) reaction $\&$ in remaining $66 / 69(95.65 \%)$ patches, $(+)$ reaction was observed. However after $96 \mathrm{hrs}$, only5/83(6.02\%) patches showed $(++)$ reaction \& in remaining 78/83(93.98\%) patches, $(+)$ reaction was seen.

\section{(C) SENSITIVITY PATTERN OF TOPICAL ANTIBACTERIALS}

Majority of cases i.e. 32/53(60.38\%) tested positive to only one antibacterial. 15/53(28.30\%) cases showed sensitivity to two antibacterials, $4 / 53(7.55 \%)$ cases showed sensitivity to three antibacterials and 1/53(1.89\%) case each showed sensitivity to four \& five topical antibacterials respectively. (Table III) (Fig1\& 2.)

\section{Figure 4}

Table III: Cases showing sensitivity pattern of topical antibacterials.

\begin{tabular}{|l|l|l|}
\hline No. of antibacterials & Number of cases & Percentage \\
\hline One & 32 & 60.38 \\
\hline Two & 15 & 28.30 \\
\hline Three & 4 & 7.55 \\
\hline Four & 1 & 1.89 \\
\hline Five & 1 & 1.89 \\
\hline Total & 53 & 100.0 \\
\hline
\end{tabular}

\section{Figure 5}

Fig1. Showing (+) Positive patch test reaction to Neosporin (Patch No.1) and (++) Positive patch test reaction to Dettol (Patch No.13)
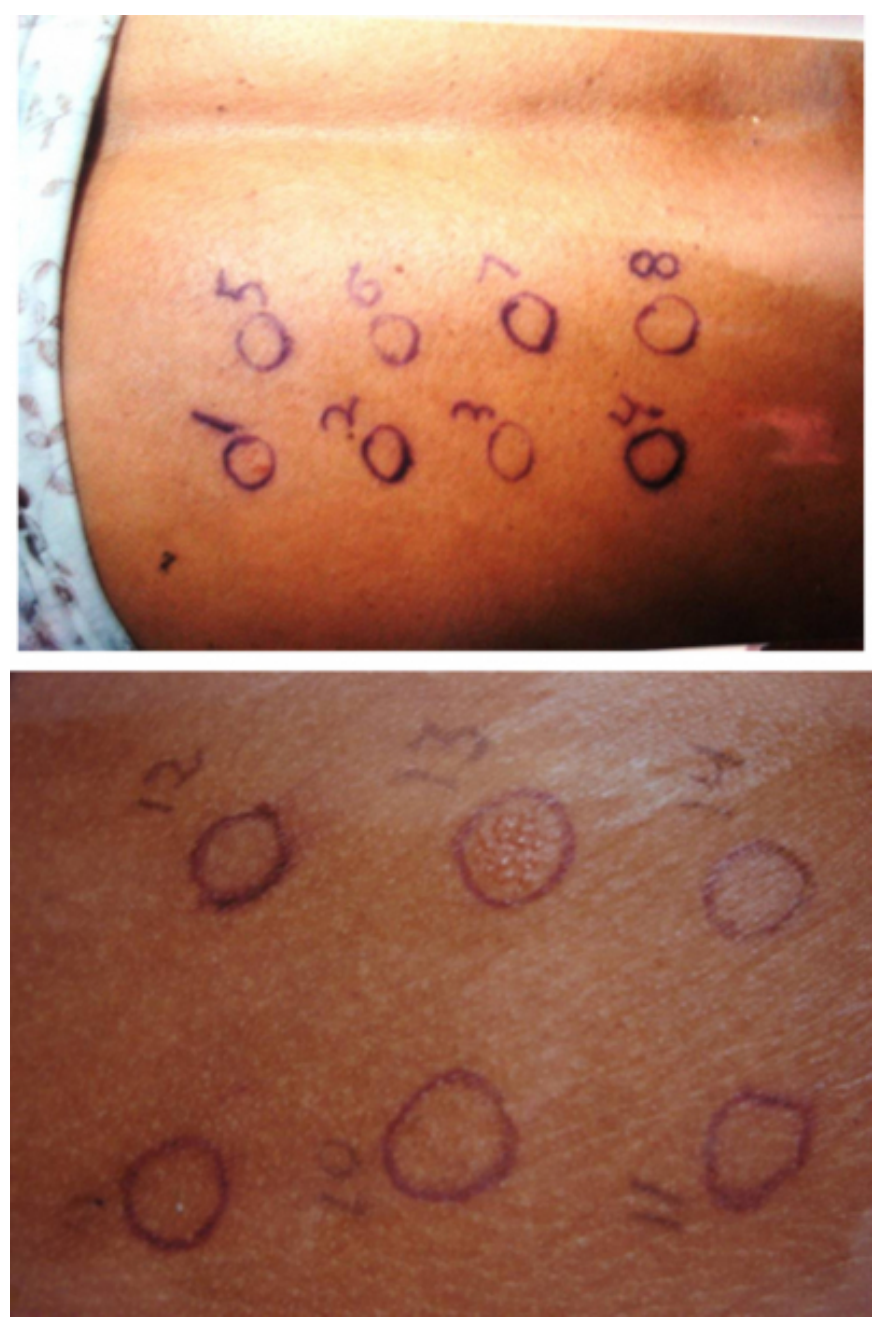


\section{Figure 6}

Fig 2. Showing magnified view of (+) Positive patch test reaction to Neosporin (Patch No.1) and (++) Positive patch test reaction to Dettol (Patch No.13)
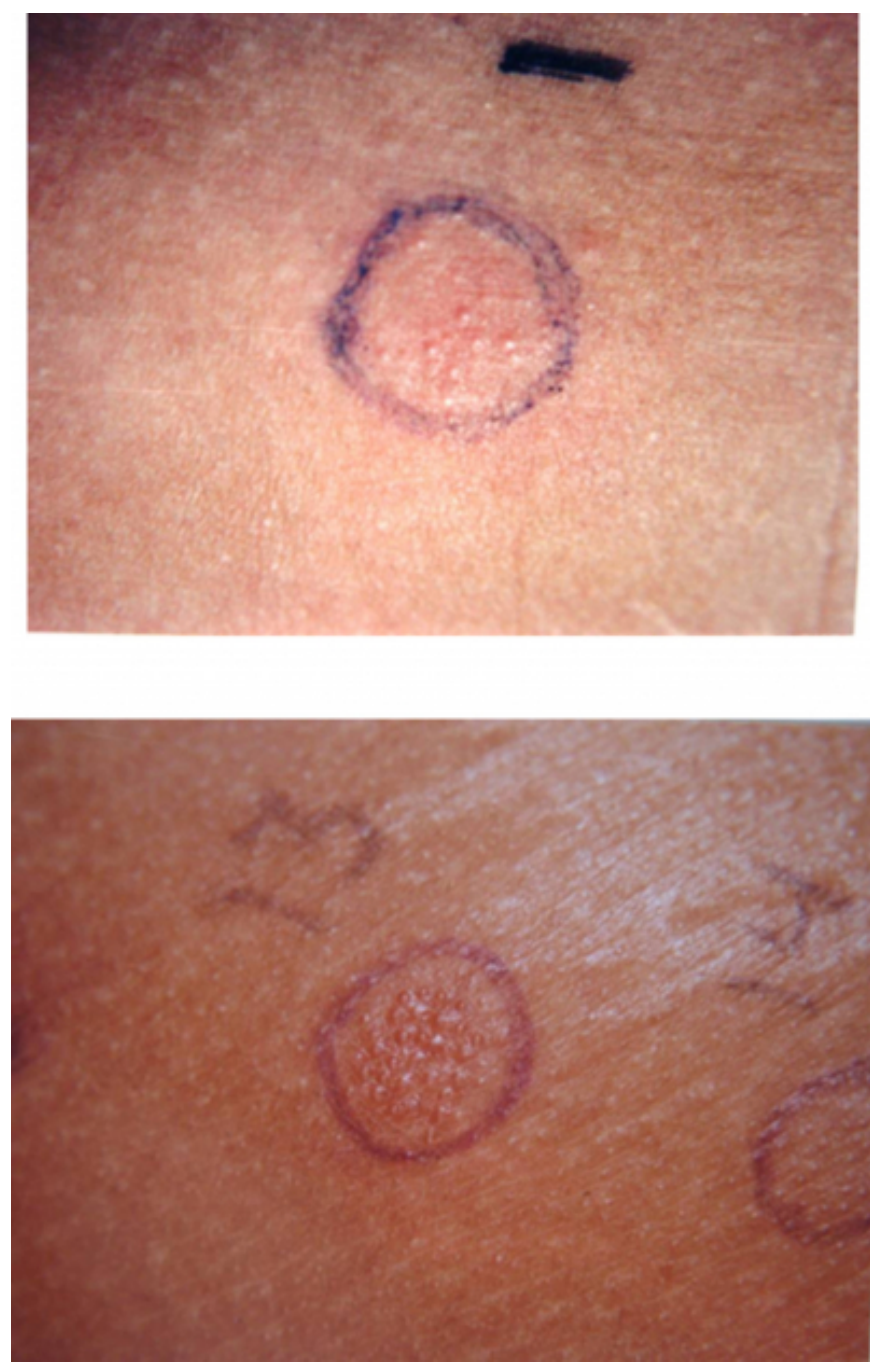

\section{CROSS SENSITIVITY TO TOPICAL ANTIBACTERIALS}

Maximum cross sensitization was seen with Neosporin (neomycin sulphate), Soframycin (framycetin), Ensamycin (sisomycin) and Furacin (nitrofurazone). Neosporin scored the highest positive tests in $20(6.67 \%)$ cases. $8(40 \%)$ cases were sensitive to Neosporin (neosporin), and $12(60 \%)$ cases were sensitive to other antibiotics also, the highest association was seen with Soframycin (framycetin) in 4(33.33\%) cases. Soframycin(framycetin) gave positive patch test in $10(3.33 \%)$ cases. $4(40 \%)$ cases alone were sensitive to it \& in $6(60 \%)$ cases it was associated with other antibiotics \& the commonest association was with Neosporin (neomycin) in 4(66.6\%) cases. Ensamycin (erythromycin) gave positive reaction in $10(3.33 \%)$ cases. $4(40 \%)$ cases were sensitive alone to Ensamycin(erythromycin) while
$6(60 \%)$ were sensitive to other antibacterials as well; the highest association was seen with Soframycin (framycetin) in 3(50\%) cases. Furacin (Nitrfurazone) alone gave positive reaction in $10(3.33 \%)$ cases. $6(60 \%)$ cases were sensitive alone to Furacin (nitrofurazone) while 4(40\%) cases were sensitive to other antibiotics also; the highest association was with Neosporin (neomycin) in 2(66.67\%) cases. (Table IV)

\section{Figure 7}

Table IV: Showing pattern of association of sensitivities among various topical antibacterials.

\begin{tabular}{|l|l|l|l|l|l|}
\hline $\begin{array}{l}\text { Topical } \\
\text { antibacterial } \\
\text { (Brand name) }\end{array}$ & $\begin{array}{l}\text { No. of } \\
+ \text { ve } \\
\text { cases }\end{array}$ & $\begin{array}{l}\text { Alone } \\
\text { sensitivity }\end{array}$ & $\begin{array}{l}\text { With other } \\
\text { antibacterials }\end{array}$ & $\begin{array}{l}\text { Most } \\
\text { frequently } \\
\text { associated } \\
\text { sensitivity }\end{array}$ & No. of cases \\
\hline Neosporin & 20 & $8(40 \%)$ & $12(60 \%)$ & Soframycin & $4(33.3 \%)$ \\
\hline Erytop & 5 & $2(40 \%)$ & $5(60 \%)$ & Erycane & $2(40 \%)$ \\
\hline Eryacne & 6 & - & $6(100 \%)$ & Metrogyl & $3(50 \%)$ \\
\hline Soframycin & 10 & $4(40 \%)$ & $6(60 \%)$ & Neosporin & $4(66.6 \%)$ \\
\hline Furacin & 10 & $6(60 \%)$ & & Neosporin & $2(66.7 \%)$ \\
\hline Ensamycin & 10 & $4(40 \%)$ & $6(60 \%)$ & Soframycin & $3(50 \%)$ \\
\hline Fucidin & - & - & - & - & - \\
\hline Clindac A gel & 2 & - & $2(100 \%)$ & Ensamycin & $1(50 \%)$ \\
\hline Silver \\
sulphadiazine
\end{tabular}

\section{RELATIONSHIP BETWEEN HISTORY OF CONTACT \& POSITIVE PATCH TESTING:}

Incidence of positivity increased in those cases who were exposed to the antibacterials previously. There was history of contact with topical antibacterials in 145/300(48.33\%) cases and 32/145(22.08\%) tested positively while a positivity in 21/155(13.55\%) cases was also recorded though these cases had not come in contact with any antibacterials. The sensitivity incidence was significantly increased in relation to Neosporin $(\mathrm{p}<0.001) \&$ Dettol $(\mathrm{p}<0.05)$.

Difference in the incidence of positivity among other groups was statistically not found to be significant (Table V). 


\section{Figure 8}

Table V: Showing positive patch test amongst contactants v/s non contactants.

\begin{tabular}{|l|l|l|l|l|}
\hline Drugs & \multicolumn{2}{|l|}{ Contactants } & \multicolumn{2}{l|}{ Non-contactants } \\
\hline & Total cases & +ve cases & Total cases & +ve cases \\
\hline Betadine* & 80 & $2(2.5 \%)$ & 220 & $1(0.45 \%)$ \\
\hline Dettol $^{* *}$ & 28 & $2(7.14 \%)$ & 272 & $2(0.74 \%)$ \\
\hline Neosporin & 24 & $12(50 \%)$ & 276 & $8(2.90 \%)$ \\
\hline Soframycin & 19 & $1(5.26 \%)$ & 281 & $9(3.20 \%)$ \\
\hline Erythromycin & 8 & - & 292 & $11(3.77 \%)$ \\
\hline Mupirocin & 2 & - & 298 & $1(0.34 \%)$ \\
\hline Silver sulphadiazine & 1 & - & 299 & $6(2.01 \%)$ \\
\hline
\end{tabular}

$* x^{2} 1.44 \mathrm{p}>0.05$ (non significant)

$* * \mathrm{x}^{2} 5.41 \mathrm{p}<0.05$ (Significant)

$* * * x^{2} 57.02 \mathrm{p}<0.001$ (Highly significant)

$* * * * \mathrm{x}^{2} 0.52 \mathrm{p}>0.05$ (non significant)

\section{DISCUSSION}

With increasing usage of topical antibacterials in various specialties of medical sciences, the incidence of the hypersensitivity is also increasing. The incidence of sensitization may also be a direct indicator of the use of that very topical preparation in a given community, society or country.

Patch testing provides an accurate, relatively simple means of diagnosis \& helps the physician to initiate appropriate management without losing valuable time. It also serves as a future guide for developing newer topical antibacterials by pharmacologists.

In our study, among 300 cases, only 53(17.67\%) cases gave positive patch tests to 13 topical antibacterials. Out of these, $32(60.38 \%)$ cases were found to be allergic to only one topical agent while rests of 21 (39.62\%) cases were sensitive to more than one topical antibacterials. In only one case, sensitivity to 5 topical antibacterials was recorded.

Sensitivity to Neosporin (Neomycin sulphate) was highest in 20/300(6.67\%) cases followed by Soframycin (Framycetin), Ensamycin (Sisomycin) and Furacin (Nitrofurazone).

Allergic response was seen to all the later three antibacterials in $10(3.37 \%)$ cases. Fischer $(1982)^{4}$, Goh et al (1983) and C. A. Menezes de Pádua et al $(2005)^{8}$ found Neomycin to be the commonest sensitizer while Pasricha and Guru (1981) ${ }^{2}$ and Bajaj et al (1986) ${ }^{6}$ found it to be second commonest sensitizer after Nitrofurazone accordingly for $40 \%$ and $35 \%$ cases respectively. In a recent study conducted by Amit Vij, P Madava Murthy, K Ravindra comparing neomycin with cosmetic agents, neomycin was found to be a more common sensitizer. ${ }^{9}$.This difference could be due to the fact that topical antibacterials in use in a community vary from time to time and from place to place which influences the result of topical antibacterial sensitivity index. In our study, 24 patients gave history of previous contact with Neosporin while none had come in contact with Furacin. Since there is an increased frequency of usage of Neosporin than Furacin, our results are self explanatory.

Fucidin (Fusidic Acid) was found to have no allergic reaction while other least common sensitizer was Mupirax (Mupirocin) sensitivity to which was seen in only $1(0.33 \%)$ case. Bajaj et al (1986) reported Sodium Fusidate to be the least sensitizer which was found to be sensitive in $1.8 \%$ cases in their study. ${ }^{6}$ In a study conducted by Morris et al $(2002)^{10}$, Fusidic Acid was found to be ten times less allergenic than neosporin. Shelansky et al (1996) reported very low incidence of sensitivity to Mupirocin $(<1 \%)$. So these two drugs can be used safely for topical use in majority of patients. ${ }^{7}$ Aluminium discs were found to be nonallergenic \& only $2(0.67 \%)$ cases showed hypersensitivity to micropore tape.

\section{CONCLUSIONS}

From the aforesaid study, it can be concluded that contact hypersensitivity to certain topical antibacterials is quite common. Since some degree of sensitizing potential is seen with most of the antibacterials, so it is advisable that topical antibacterials usage should not be indiscriminate $\&$ limited to specific needs. Since sodium fusidate was the only antibacterial which is found to be completely non allergenic in our study and mupiricin was least allergenic so these two antibacterials can be safely recommended for use in medical practice.

\section{References}

1. Bandmann HJ, Calnan CD, Fregert S. Dermatitis from applied medicaments. Arch Dermatol. 1972; 106:335-37. 2. Pasricha JS, Guru. Contact hypersensitivity to local antibacterial agents. Ind.J.Derm.Vener.Leper. 1981; 47(1):27-30.

3. Rietschel Robert L, New Orleans, Louisiana. Human and economic impact of allergic contact dermatitis and the role of patch testing. Journal of American Academy of Dermatology, 1995;49(5):812-15.

4. Fischer AA. Topical medicaments which are common sensitizers. Ann Allergy. 1982 Aug; 49(2):97-100.

5. Goh CL, Hed M. Contact sensitivity to topical medicaments. International Journal of Dermatology, 1989; 28:25-28. 
6. Bajaj AK, Gupta SC. Contact hypersensitivity to topical antibacterial agents. International Journal of Dermatology 1986; 25:103-5.

7. Shelanski MV, Phillips SB, Potts CE. Evaluation of cutaneous reactivity to recently marketed dermatologic products. Int. J Dermatol. 1996 Feb; 35(2):137-40.

8. Menezes de Pádua CA, Schnuch A, Lessmann H, Geier J, Pfahlberg A, Uter W. Pharmacoepidemiol Drug Saf. 2005 Oct; 14(10):725-33.
9. Amit Vij, P Madava Murthy, K Ravindra. Study of contact dermatitis due to topical medicaments and cosmetics by patch testing. Indian Journal of dermatology. 2007; 52(4):194-7.

10. Morris SD, Rycroft RJ, White IR, Wakelin SH,

McFadden JP. Comparative frequency of patch test reactions to topical antibiotics. Br J Dermatol. 2002 Jun;146(6):1047-51 


\section{Author Information}

Suresh Kumar Malhotra, MD

Associate Professor, Department of Skin \& STD, Govt. Medical College, Amritsar 143001(India)

\section{Suraj Parkash Dewan, MD}

Professor (Ex), Department of Skin \& STD, Govt. Medical College, Amritsar- 143001(India)

\section{Anjum Singal, MD}

Junior Resident (Ex), Department of Skin \& STD, Govt. Medical College, Amritsar- 143001(India)

\section{Manjit Kaur, MBBS}

Junior Resident, Department of Skin \& STD, Govt. Medical College, Amritsar- 143001(India) 